\title{
Coalition for Networked Information: The second year, part 2
}

\author{
By Thomas G. Kirk \\ College Librarian \\ Berea College
}

\author{
and Noreen S. Alldredge
}

Dean of Libraries
Montana State University
I $\mathrm{n}$ an effort to be a catalyst for the development of networked information services, the Coalition for Networked Information (CNI) begins an ambitious set of activities in 1991-92. The November 21-22 meeting of the Task Force of the Coalition for Networked Information focused on the developing program of the Coalition during its second year. The meeting included sessions of the eight working groups, some of which were reviewed in the January issue of $C \& R L$ News. In addition, the meeting included several major papers and reviewed a variety of individual projects (Project Briefings) and specific points of interest (Synergy Sessions) which relate to networked information. Some of the Project Briefings and Synergy Sessions

\section{Katz proposed a costing method- ology ... [that] called for careful definition of the units of analysis and the need for generally accepted accounting practices.}

are highlighted in this issue along with summaries of some of the major papers.

The CNI fall meeting began with presentations on the economics information flow by Richard N. Katz (special assistant, Information Systems and Administration Services) and Czeslaw Jan Grycz (Scholarship and Technology Study Project) both from the University of California. In "Academic Information Management at the Crossroads: Time Again to Review the Economics" Katz presented a model for cost centers in the flow of printed information which might be used to establish a baseline for analyzing the economics of alternative models of networked information flow.

After setting the context by reviewing the current state of higher education, development of net- worked information services, and life cycles of technological change, Katz proposed a costing methodology. He called for careful definition of the units of analysis and the need for generally accepted accounting practices for handling these units of analysis.

Katz's costing model for printed material included the cost to (1) generate the material which he equated with the price paid by institution to obtain the material. Additional components of the costing model included (2) processing (selection, content control, and inventory control), (3) storage (conservation and preservation, facility construction and maintenance, equipment), and (4) circulation (circulation logistics, reference services, document delivery, customer time).

\section{Synergy sessions}

- Newsgroups, censorship, and policy in advance led by Peter Graham (Rutgers University).

- Networked information systems: can we really measure their costs and effectiveness led by Ronald Nayłor (University of Miami) and Sarah Pritchard (ARL).

- The University Licensing Program(TULIP) led by Karen Hunter of Elsevier Science Publishers.

- Interoperability of networked information systems and services led by Clifford Lynch (director of library automation, office of the president, University of California).

- Coalition network services led by Craig Summerhill (CNI) reviewed plans for the development of the CNI server and other networked information services. 
Grycz reviewed seven models of the economics of networked information. The seven models are:

Acquisitions on demand model

National site licensing model

Discipline specific distribution services model

Augmented print model

Distributed information model

National Public Radio-like model

Baseline model (Katz's previously presented model)

For each he drew attention to financial and policy issues which need to be addressed if the economics of the models are to be understood and compared with one another.

\section{Project briefings}

- Distributed Audio Database System (DADS) is a project of the Belfer Audion Lab \& Archive at Syracuse University reported by William Storm.

- CLASS (Comell University) and Digital Preservation Project (Yale University) which are preservation projects using scanning technology to capture book page images electronically.

- The Synthesis Coalition for Engineering Education (reported by David Martin, engineering network coordinator, Iowa State University, and John Syalor, Engineering Library, Cornell University) is a project to develop educational materials in electronic format.

- The Chronicle of Higher Education Online project reported by Judith Turner, director of Chronicle Information Services, explained the effort to develop databases of Chronicle information for remote access or loading on a local information network.

- Knowledge Management project-model developed at Johns Hopkins which is a collaboration between libraries and the information community. This moves libraries from the storage/retrieval mode to one of information transfer and then to knowledge management. Richard Lucier, now at the University of California at San Francisco, intends to further develop this model thus involving the library at the beginning of the scholarly communication process.

- New pathways to a college degree reported by Steve Ehrmann is an effort by the Annenberg/CPB Project to provide educational materials in electronic and multimedia formats.
An abbreviated version of Katz's paper and much of the content of Grycz's presentation, but not written by him, are included in an issue of Serials Review (volume 18, no. 1/2) which will be published spring 1992. This will be a useful summary of current thinking about the economics of electronic information.

In a related matter, Paul Peterson, executive director of CNI, announced the establishment of CNI's Rights for Electronic Access to and Delivery of Information (READI) Program. “The Coalition's Working Group on Modernization of Scholarly Publication seeks to evaluate whether the concept of using contract law, in the form of licenses and related agreements between creators and users of published works, can be employed within the context of copyright law to facilitate the flow of networked information. This effort starts from the assumption that present copyright law may not need to be changed but that through contracts copyright ownership can be preserved while providing for use of information in electronic form. It is the Coalition's intent to develop a 'straw' proposal which will promote dialogue and comment among the various parties of rights holders and Coalition members." (CNI Conference documents.) It is expected that the program documents can be reviewed by the Coalition's Task Force at its spring 1992 meeting.

Douglas Greenberg (vice president, American Council of Learned Societies) capped off the Thursday program with an after-dinner address on the state of and prospects for networked information resources and services in the humanities, arts, and social sciences. Greenberg characterized the humanities and arts as ready for networked information but because of the inadequate funding of humanities research and the lack of useful material in electronic form he saw significant problems in making networked information available to humanities scholars. He called for a greater effort to convert older materials to machine-readable form in order to make more machine-readable materials available for humanities and arts scholars. However, he was not sanguine about the funding for such efforts.

Lewis M. Branscomb (Albert Pratt public service professor and director of the Science, Technology and Public Policy Program at the John F. Kennedy School of Government at Harvard University) spoke on public policy processes by which NREN might be developed. The processes were defined as the diffusion-, mission- or producer-oriented. Branscomb called for a diffusion-oriented process because it provides a "capability enabling policy." The capability enabling policy provides a flexible approach which American society needs.

The next meeting of the Coalition Task Force will be March 25-27, 1992. 